Research Article

\title{
Urea Application Rate for Crop Straw Decomposition in Temperate China
}

\author{
Y. Wang $\left(\mathbb{D},{ }^{1}\right.$ H. Wang, ${ }^{2}$ C. Gao, ${ }^{1}$ P. A. Seglah $\mathbb{D},{ }^{1}$ and Y. Bi $\mathbb{D}^{1}$ \\ ${ }^{1}$ Institute of Agricultural Resources and Regional Planning, Chinese Academy of Agricultural Sciences, Beijing 100081, China \\ ${ }^{2}$ Institute of Agricultural Information, Chinese Academy of Agricultural Sciences, Beijings, China \\ Correspondence should be addressed to Y.Bi; biyuyun@caas.cn
}

Received 2 May 2021; Revised 3 September 2021; Accepted 29 October 2021; Published 30 November 2021

Academic Editor: Oliver Dilly

Copyright $\odot 2021$ Y. Wang et al. This is an open access article distributed under the Creative Commons Attribution License, which permits unrestricted use, distribution, and reproduction in any medium, provided the original work is properly cited.

\begin{abstract}
Returning straw to the field has become the most important straw utilization method in China. The aim of this research was to study the appropriate amount of nitrogen fertilizer applied when returning the straw of three major crops (wheat, rice, and corn) to the field in areas under low to high yield levels based on the demand of nitrogen for microbial decomposition of straw. Under the condition of returning $100 \%$ straw to the field, we developed the formula for calculating the nitrogen application rate and estimated the urea application rate for the three major grain crops. The results showed that returning straws of wheat, early-season rice, middle-season rice and late-season rice, and corn to the field with urea application at the rate of about $150 \mathrm{~kg} / \mathrm{ha}, 120 \sim$ $135 \mathrm{~kg} / \mathrm{ha}, 75 \mathrm{~kg} / \mathrm{ha}$, and $75 \sim 90 \mathrm{~kg} / \mathrm{ha}$, respectively, can provide sufficient nitrogen for microbial decomposition. The urea application rate for returning $100 \%$ wheat straw to the field in Huang-Huai-Hai region, Middle-Lower Yangtze region, Loess plateau region, and Northwest arid region was $135-230 \mathrm{~kg} / \mathrm{ha}, 110-190 \mathrm{~kg} / \mathrm{ha}, 85-145 \mathrm{~kg} / \mathrm{ha}$, and $95-165 \mathrm{~kg} / \mathrm{ha}$, respectively. $52.5-98.5 \mathrm{~kg} / \mathrm{h}$ o of urea was used for $100 \%$ early rice straw returning to the field in Middle-Lower Yangtze region and South China. In addition, the urea application rate for $100 \%$ middle-late rice straw returning to the field was $95-180 \mathrm{~kg} / \mathrm{ha}, 100-185 \mathrm{~kg} / \mathrm{ha}$, $95-175 \mathrm{~kg} / \mathrm{ha}$, and $75-140 \mathrm{~kg} / \mathrm{ha}$, respectively. The rate of urea application for $100 \%$ corn straw returning to the field in Northeast China, Huang-Huai-Hai, Northwest arid region, and Southwest China was $60-135 \mathrm{~kg} / \mathrm{ha}, 50-115 \mathrm{~kg} / \mathrm{ha}, 60-135 \mathrm{~kg} / \mathrm{ha}$, and 45-105 kg/ha, respectively. The amount of nitrogen fertilizer required for the total return of crop straw is not only affected by crop straw $\mathrm{C}: \mathrm{N}$, yield per unit area, and ratio of grass to grain but also affected by straw returning mode, regional nitrogen application level, and other factors. Therefore, the amount of nitrogen fertilizer should be adjusted according to the type of cropping system, soil, and climatic conditions of the specific location. This substantial $\mathrm{N}$ input for stimulating straw decomposition may favor $\mathrm{N}$ losses with nitrate leaching and nitrous oxide emissions and hold a potential for soil $\mathrm{N}$ eutrophication in the long term if the level is not carefully adjusted to the $\mathrm{N}$ requirement of the subsequent crops and changes in soil organic matter levels.
\end{abstract}

\section{Introduction}

Returning straw to the field has gained recognition worldwide as the major method of straw utilization [1], and this practice is essential in China. It is considered as one of the sustainable techniques that stimulate good soil health [2]. In addition, it is encouraged and publicized as an economic approach and provides a good source of nutrients to the soil [3]. Returning an amount of straw to the field can improve the soil physical and chemical properties and reduce the soil bulk density and the degree of soil compaction. It also increases the organic matter content of the soil by increasing the level of total nitrogen, phosphorus, potassium, and other nutrients. At present, returning straw directly to the field is the leading method of comprehensive utilization of straw in China. The final assessment results of the comprehensive utilization of straw in the $12^{\text {th }}$ Five-Year Plan of China [4] showed that the fertilizer utilization of straw reached 390 million tons in 2015, of which about 375 million tons were returned directly to the field, accounting for $41.7 \%$ of the collectable resources of straw. However, the proportion of straw returned to the field directly in developed countries has reached about two-thirds [5]. This implies there is enormous potential in returning straw to the field in China. 
In the process of returning straw to the field, the suitable $\mathrm{C}$ : $\mathrm{N}$ is (24-35):1. The $\mathrm{C}: \mathrm{N}$ of major crops such as wheat, rice, corn, cotton, and oilseed rape is as high as (55-85):1. Therefore, it is often required to apply a certain amount of nitrogen $(\mathrm{N})$ fertilizer to promote the rapid decomposition of straw and avoid soil "nitrogen starvation" [6].

According to different regions and the characteristics of different returning crop materials and the quantity returned to the field, a reasonable application of nitrogen fertilizer should be considered. In Asia, urea accounts for $75 \%$ of the total $\mathrm{N}$ fertilizer which makes it the leading $\mathrm{N}$ fertilizer [7]. To guarantee sustainability, it is important to retain an adequate amount of fertilizer (NPK) and ensure that its distribution in soils is balanced [8]. According to Quan et al. [9] to accomplish sustainable nitrogen supply and crop productivity and prevent soil degradation, there is the requisite to improve the management of nitrogen to prevent deficient or excessive soil nitrogen levels in China. Quantifying the right amount of nitrogen fertilizer is of immense significance to improve the quality of straw returning to the field, and the efficiency of nitrogen fertilizer utilization to reduce environmental hazards. At present, there are problems such as high dosage of nitrogen, low efficiency rate, and high level of pollution in agricultural production in China [10]. Although the yield per unit area of the crop is slightly lower than that in some developed countries, the application intensity of nitrogen fertilizer is twice as high as that in developed countries [11]. From 1980s to 2000s, farmers normally overapplied $\mathrm{N}$ fertilizer, which triggered acidification of Chinese farmlands with a decrease in 0.5 unit $\mathrm{pH}$ of the topsoil. Applying high quantities of nitrogen fertilizer implies a low nitrogen use efficiency and negative impact on the environment [12]. Hence, optimum application of $\mathrm{N}$ fertilizer in terms of right time and rate helps to increase crop productivity and reduce leaching [13].

In this regard, researchers have conducted studies on the correlation between nitrogen fertilizer application and crop yield, soil water and fertility conditions, and the appropriate amount of nitrogen to be applied under different tillage conditions $[14,15]$. A large number of field experiments have shown that a quadratic parabola relationship exists between crop yield and the quantity of nitrogen applied. This implies crop yield increases gradually with the increase in the rate of $\mathrm{N}$ applied, but the amount of nitrogen applied should be efficient. If nitrogen application exceeds the right amount, there will be a decrease in crop yield [15]. Studies by Henriksen and Breland [16] indicated that, when the available nitrogen is greater than $1.2 \%$ of the dry weight of wheat straw, it inhibits soil microbial growth. According to McSwiney and Robertson [17], for the same soil and crop type, if the amount of $\mathrm{N}$ fertilizer applied is less or close to the demand of crop nitrogen fertilizer, nitrous oxide $\left(\mathrm{N}_{2} \mathrm{O}\right)$ emissions will be lower. On the other hand, if nitrogen fertilizer application exceeds crop demand, $\mathrm{N}_{2} \mathrm{O}$ emissions will be higher. In China, most research on appropriate nitrogen application concentrated on wheat or corn planting experiments under the conditions of corn straw returning to the field in one-year double cropping or one-year single cropping. A few experiments were conducted on the nitrogen application rate of rice planting under the condition of returning wheat straw to the field $[15,18,19]$. In response to the situation of different crop straw returning to the field, a large number of site-specific experiments on nitrogen fertilizer application were conducted in China. However, the research on nitrogen fertilizer application during straw returning to the field, especially from the perspective of meeting the basic requirements of microbial decomposition for nitrogen, is relatively underdeveloped. Specifically, the application rate of nitrogen fertilizer during straw returning to the field is the incremental application rate of nitrogen fertilizer based on the conventional application rate. Quantifying the right amount of nitrogen fertilizer for crops is an essential aspect in agriculture [20]. There is the need to consider major regions in the national estimation of nitrogen use efficiency (NUE) [9] and other crops. Therefore, it is important to promote the application of $\mathrm{N}$ fertilizer and straw returning to advance efficient utilization of resources as an environmental protection strategy [21]. Based on the primary demand for nitrogen in microbial decomposition during straw returning to the field, this research seeks to develop a formula for calculating the total application rate of nitrogen fertilizer during 100\% straw returning to the field with different yields per unit area and according to yield per unit area of the crop. This paper develops a urea application rate enquiry table for $100 \%$ straw returning to the field with different yields per unit area of three major grain crops (wheat, rice, and corn) and a urea application amount enquiry table for $100 \%$ straw returning to the field for the three major grain crops in different regions and provinces (municipalities and autonomous regions; Hong Kong, Macao, and Taiwan are not included within the scope of this paper) of China. The aim of this research was to study the appropriate amount of nitrogen fertilizer applied when returning the three major crop straws (wheat, rice, and corn) to the field in different areas under different yield levels based on the basic demand of nitrogen for microbial decomposition of straw. In the end, this paper put forward considerations and suggestions on the nitrogen fertilizer application for straw returning to the field, acting as a reference for different regions of China.

\section{Materials and Methods}

2.1. Calculation Method of Fertilizer Application for $100 \%$ Straw Returning to the Field. Based on the primary demand for nitrogen in microbial decomposition, the formula for calculating the amount of nitrogen fertilizer to be applied during $100 \%$ straw returning to the field of different crops is

$$
y=\frac{S_{G} \times P \times N_{S} \times\left(S_{C: N}-M_{C: N}\right)}{N_{F} \times M_{C: N}},
$$

where $y$ is the nitrogen fertilizer application rate during straw returning to the field in kilogram per hectare $(\mathrm{kg} / \mathrm{ha})$, $S_{G}$ is the straw/grain ratio, $P$ is the yield per unit area of the crop (kg/ha), $N_{S}$ is the nitrogen content of the straw (\%), $N_{F}$ is the nitrogen content of nitrogen fertilizer (\%), $S_{C: N}$ is the straw $\mathrm{C}: \mathrm{N}$ ratio, and $M_{C: N}$ is the $\mathrm{C}: \mathrm{N}$ ratio of materials 
suitable for microbial decomposition. The straw/grain ratio $\left(S_{G}\right)$ is shown in Table 1, the nitrogen content of nitrogen fertilizer $\left(N_{F}\right)$ is shown in Table 2, and the C: $\mathrm{N}$ ratio of materials suitable for microbial decomposition $\left(M_{C: N}\right)$ is shown in Tables 2 and 3.

In the case of corn straw returning to the field with urea application, the straw/grain ratio of corn $\left(S_{G}\right)$ is 1.1, the nitrogen content of corn straw $\left(N_{S}\right)$ is $0.75 \%$ (Table 2), and the nitrogen content of urea $\left(N_{F}\right)$ is $46.67 \%$. In addition, the carbon-nitrogen ratio of corn straw $\left(S_{C: N}\right)$ is $53: 1$ (Table 1) and material $\mathrm{C}: \mathrm{N}$ ratio $\left(M_{\mathrm{C}: \mathrm{N}}\right)$ suitable for microbial decomposition is $30: 1$, with the assumption that the yield per unit area of corn (P) is $6000 \mathrm{~kg} / \mathrm{ha}$ which is the average national corn yield per $\mathrm{mu}(1 \mathrm{mu}=0.0667$ hectare $)$ from 2015 to 2017. The total urea application rate during corn straw returning to the field is shown in

$$
y=\frac{1.1 \times 6000 \times 0.75 \times(53-30)}{46.67 \times 30} \approx 81.3(\mathrm{~kg} / \mathrm{ha}) .
$$

Equation (1) was used to calculate the amount of nitrogen fertilizer application rate during 100\% straw returning to the field of different crops and three major grain crops (wheat, rice, and corn). We took $35: 1,30: 1$, and $25: 1$ as the $C: N$ adjustment targets, based on the parameter values (Tables 1 and 2). We calculated the urea application rate for $100 \%$ straw returning to the field with different yields per unit area of three major grain crops and the urea application rate for $100 \%$ straw returning to the field in different regions and provinces (municipalities and autonomous regions) of China. The 2015-2017 national crop yield data were used [25-27]. The national average wheat yield was about $5424 \mathrm{~kg}$ per hectare with a remarkable amplitude of variation between 2250 and $7500 \mathrm{~kg}$. For $5250 \mathrm{~kg}$ as the median value and $375 \mathrm{~kg}$ as the grade differential with floating \pm 10 grades, the national wheat yield per unit area was divided into 21 grades. For early rice yield, the national average per hectare was about $5851 \mathrm{~kg}$ with a remarkable amplitude of variation between 5250 and $6750 \mathrm{~kg}$. For $6000 \mathrm{~kg}$ as the median value and $375 \mathrm{~kg}$ as the grade differential with floating \pm 6 grades, the national early rice yield per unit area was divided into 13 grades.

The national average middle-late rice yield per hectare was about $5850 \mathrm{~kg}$, with a remarkable amplitude of variation between 5250 and $9000 \mathrm{~kg}$. For $7125 \mathrm{~kg}$ as the median value and $375 \mathrm{~kg}$ as the grade differential with floating \pm 7 grades, the national middle-late rice yield per unit area was divided into 15 grades. For corn yield, the national average per hectare was about $5993 \mathrm{~kg}$ with a remarkable amplitude of variation between 4500 and $7500 \mathrm{~kg}$. We took $6000 \mathrm{~kg}$ as the median value and $375 \mathrm{~kg}$ as the grade differential with floating \pm 8 grades, and the national corn yield per unit area was divided into 17 grades. In addition, we calculated the amount of urea applied for $100 \%$ wheat straw, early rice straw, middle-late rice straw, and corn straw returning to the field in different regions and provinces in China, and the average regional values were calculated according to the average yield per unit area.
2.2. Straw/Grain Ratio and Straw C:N of Major Crops. The straw of wheat, rice, corn, millet, sorghum, cotton, oilseed rape, sunflower, tobacco, and others has high $\mathrm{C}: \mathrm{N}$, mostly around (60-70):1 (Tables 2 and 3). Wheat straw has the highest $C: \mathrm{N}$ of $87: 1$, whereas corn straw and sorghum straw have lower $C: N$ of $53: 1$ and $55: 1$, respectively [23]. The application of nitrogen fertilizers such as urea, ammonium bicarbonate, and diammonium phosphate $\left((\mathrm{NH} 4)_{2} \mathrm{HPO}_{4}\right)$ is required when all the crop straws are returned to the field. The $\mathrm{C}: \mathrm{N}$ rate in most straws of $\mathrm{cu}-$ curbits and vegetables, tuber crops, and sugar-yielding crops is below $35: 1$ [24] (Table 3).

2.3. Suitable C:N for Microbial Decomposition of Straw. Carbon and nitrogen are essential nutrients for the microbial decomposition of straw [28]. High C: N (excess carbon and deficient nitrogen) affects microbial metabolism and growth and undermines reproduction which negatively affects straw decomposition [29]. If the $\mathrm{C}: \mathrm{N}$ value is higher than $35: 1$, the microorganisms need to undergo multiple life cycles to oxidize the excess carbon until a suitable $\mathrm{C}: \mathrm{N}$ value is reached for their metabolism [28]. If the $\mathrm{C}: \mathrm{N}$ is too low (less than $20: 1$ ), there is less carbon available for consumption and excess nitrogen nutrients will cause nitrogen volatilization and reduce soil fertilizer efficiency. On average, 1 part of nitrogen is generally required for every 30 parts of carbon the microorganisms utilize [30]. So, the $\mathrm{C}: \mathrm{N}$ should be adjusted at $30: 1$, which is best suited for microbial decomposition of straw.

\section{Results}

3.1. Urea Application Rate for 100\% Wheat Straw Returning to the Field. The urea application rate enquiry table for $100 \%$ wheat straw returning to the field with different yields per unit area has been calculated and prepared in grades (shown in Table 4). Table 4 shows that according to the C: $\mathrm{N}$ adjustment targets of $35: 1,30: 1$, and $25: 1$ under the national actual average yield per unit area of wheat, the urea application rate is about $120 \mathrm{~kg} / \mathrm{ha}, 150 \mathrm{~kg} / \mathrm{ha}$, and $195 \mathrm{~kg} / \mathrm{ha}$, respectively, for $100 \%$ wheat straw returning to the field. The urea application rate at about $150 \mathrm{~kg} / \mathrm{ha}$ can generally meet the nitrogen demand for microbial decomposition of $100 \%$ wheat straw returning to the field in China.

According to the $\mathrm{C}: \mathrm{N}$ adjustment targets of $35: 1,30: 1$, and $25: 1$ (Table 5), the urea application rates for $100 \%$ wheat straw returning to the field in four major regions in China are $135-230 \mathrm{~kg} / \mathrm{ha}, \quad 110-190 \mathrm{~kg} / \mathrm{ha}, \quad 85-145 \mathrm{~kg} / \mathrm{ha}$, and $95-165 \mathrm{~kg} / \mathrm{ha}$ in Huang-Huai-Hai region, Middle-Lower Yangtze region, Loess plateau region of China, and Northwest arid region of China, respectively. The regions of China are shown in Figure 1.

\subsection{Amount of Urea Application for $100 \%$ Early Rice Straw} Returning to the Field. Table 6 shows that according to the C: $\mathrm{N}$ adjustment targets of $35: 1,30: 1$, and $25: 1$ under the national actual average yield per unit area of early rice, the urea application rate is about $52.5 \mathrm{~kg} / \mathrm{ha}, 75 \mathrm{~kg} / \mathrm{ha}$, and $97.5 \mathrm{~kg} / \mathrm{ha}$, respectively, for $100 \%$ early rice straw returning to the field. The 
TABLE 1: Ratio of straw to grain.

\begin{tabular}{lclc}
\hline Types of straw & Ratio of straw to grain & Types of straw & Ratio of straw to grain \\
\hline (1) Rice & 0.95 & $(11)$ Sesame & 2.80 \\
Early rice & 0.68 & (12) Flax & 2.00 \\
Middle-late rice & 1.00 & $(13)$ Sunflower & 2.80 \\
(2) Wheat & 1.30 & $(14)$ Cotton & 5.00 \\
(3) Corn & 1.10 & $(15)$ Jute and kenaf & 1.90 \\
(4) Millet & 1.40 & $(16)$ Ramie & 6.50 \\
(5) Sorghum & 1.60 & $(17)$ Jute & 3.00 \\
(6) Soybean & 1.60 & $(18)$ Flax & 1.10 \\
(7) Potato & 0.96 & $(19)$ Sugarcane & 0.10 \\
(8) Sweet potato & 0.63 & $(20)$ Sugar beet & 0.10 \\
(9) Peanut & 1.50 & $(21)$ Tobacco & 1.60 \\
(10) Rape & 2.70 & $(22)$ Melon and vegetables & 0.10 \\
\hline
\end{tabular}

Data source: Bi [22].

TABLE 2: C: $\mathrm{N}$ of straw of major crops.

\begin{tabular}{lccc}
\hline Types of straw & Water content (\%) & Carbon content (\%) & Nitrogen content (\%) \\
\hline Dry wheat straw & 18 & 46 & 0.53 \\
Dry rice straw & 17 & 42 & 0.68 \\
Dry corn stover & 20 & 40 & 0.75 \\
Soybean stalks & - & 41 & 1.30 \\
Peanut seedling & - & 11 & 0.59 \\
\hline
\end{tabular}

Data source: MOA [23].

TABle 3: C: $N$ of straw of some grain and cash crops.

\begin{tabular}{ll}
\hline Types of straw & $\mathrm{C}: \mathrm{N}$ \\
\hline Millet straw & $62: 1$ \\
Sorghum straw & $55: 1$ \\
Cotton stalk & $70: 1$ \\
Rape stem & $68: 1$ \\
Sugarcane tip & $35: 1$ \\
Fruit and vegetable residues & $35: 1$ \\
Sugar beet stem & $20: 1$ \\
Sunflower stalk & $65: 1$ \\
Tobacco stem & $61: 1$ \\
Potato vine & $28: 1$ \\
Sweet potato vine & $25: 1$ \\
Melon vine & $20: 1$ \\
Waste of kale and leafy greens & $15: 1$ \\
\hline
\end{tabular}

Data source: Zuo [24].

urea application rate at about $75 \mathrm{~kg} / \mathrm{ha}$ can generally meet the nitrogen demand for microbial decomposition of $100 \%$ early rice straw returning to the field in China.

There are 10 early rice planting provinces in China, categorized into two regions. One is the early rice planting region in the Middle-Lower Yangtze region, which includes 5 provinces of Zhejiang, Anhui, Jiangxi, Hubei, and Hunan. The other is the early rice planting region in South China, which includes 5 provinces, namely, Fujian, Guangdong, Guangxi, Hainan, and Yunnan (as the only early rice growing region in Southwest China, Yunnan province is encompassed in the early rice area in South China). According to the $\mathrm{C}: \mathrm{N}$ adjustment targets of $35: 1,30: 1$, and $25: 1$ (Table 7), the urea application rate for $100 \%$ early rice
TABLE 4: Enquiry table for the urea application rate of wheat straw returning to the field with different yields per unit area.

\begin{tabular}{lccc}
\hline & \multicolumn{3}{c}{ Urea dosages of different C:N } \\
Yield per unit area of wheat & $25: 1$ & $30: 1$ & $35: 1$ \\
\hline 1500 & 54.90 & 42.15 & 32.85 \\
1875 & 68.70 & 52.65 & 41.10 \\
2250 & 82.35 & 63.15 & 49.35 \\
2625 & 96.15 & 73.65 & 57.60 \\
3000 & 109.80 & 84.15 & 65.85 \\
3375 & 123.60 & 94.65 & 74.10 \\
3750 & 137.25 & 105.15 & 82.20 \\
4125 & 151.05 & 115.65 & 90.45 \\
4500 & 164.70 & 126.30 & 98.70 \\
4875 & 178.50 & 136.80 & 106.95 \\
5250 & 192.15 & 147.30 & 115.20 \\
5625 & 205.95 & 157.80 & 123.45 \\
6000 & 219.75 & 168.30 & 131.55 \\
6375 & 233.40 & 178.80 & 139.80 \\
6750 & 247.20 & 189.30 & 148.05 \\
7125 & 260.85 & 199.80 & 156.30 \\
7500 & 274.65 & 210.45 & 164.55 \\
7875 & 288.30 & 220.95 & 172.80 \\
8250 & 302.10 & 231.45 & 180.90 \\
8625 & 315.75 & 241.95 & 189.15 \\
9000 & 329.55 & 252.45 & 197.40 \\
\hline & & &
\end{tabular}

Unit: $\mathrm{kg} / \mathrm{ha}$.

straw returning to the field is $52.5-98.5 \mathrm{~kg} / \mathrm{ha}$ in both early rice production regions in China, namely, Middle-Lower Yangtze region and South China. 
TABLE 5: Enquiry table for urea applied to wheat straw returning to the field in all regions of China and provinces (cities, autonomous regions).

\begin{tabular}{|c|c|c|c|c|c|}
\hline \multirow[t]{2}{*}{ Regions } & & \multirow{2}{*}{$\begin{array}{l}\text { Average wheat yield per unit } \\
\text { from } 2015 \text { to } 2017\end{array}$} & \multicolumn{3}{|c|}{$\begin{array}{c}\text { Urea dosages of different } \mathrm{C}: \mathrm{N} \\
\text { adjustment targets }\end{array}$} \\
\hline & & & $25: 1$ & $30: 1$ & $35: 1$ \\
\hline \multirow{4}{*}{ Northeast China } & Liaoning & 4215 & 154.40 & 118.20 & 92.39 \\
\hline & Jilin & 4286 & 156.73 & 120.26 & 94.04 \\
\hline & Heilongjiang & 3519 & 128.78 & 98.68 & 77.12 \\
\hline & Average & 3553 & 130.02 & 99.64 & 77.86 \\
\hline \multirow{6}{*}{ Huang-Huai-Hai region of China } & Beijing & 5375 & 196.83 & 150.74 & 117.86 \\
\hline & Tianjin & 5567 & 203.77 & 156.21 & 122.14 \\
\hline & Hebei & 6240 & 228.45 & 175.05 & 136.80 \\
\hline & Shandong & 6135 & 224.55 & 172.05 & 134.55 \\
\hline & Henan & 6426 & 235.27 & 180.32 & 140.98 \\
\hline & Average & 6285 & 230.10 & 176.25 & 137.85 \\
\hline \multirow{8}{*}{ The Middle-Lower Yangtze region of China } & Shanghai & 4241 & 155.30 & 119.02 & 93.03 \\
\hline & Jiangsu & 5286 & 193.47 & 148.25 & 115.90 \\
\hline & Zhejiang & 3777 & 138.24 & 105.99 & 82.86 \\
\hline & Anhui & 5744 & 210.26 & 161.07 & 125.98 \\
\hline & Jiangxi & 2117 & 77.52 & 59.34 & 46.37 \\
\hline & Hubei & 3804 & 139.28 & 106.63 & 83.42 \\
\hline & Hunan & 3230 & 118.28 & 90.62 & 70.88 \\
\hline & Average & 5176 & 189.49 & 145.23 & 113.57 \\
\hline \multirow{5}{*}{ South China } & Fujian & 3200 & 117.13 & 89.79 & 70.21 \\
\hline & Guangdong & 3043 & 111.38 & 85.29 & 66.71 \\
\hline & Guangxi & 1667 & 60.98 & 46.79 & 36.56 \\
\hline & Hainan & - & - & - & - \\
\hline & Average & 2099 & 76.86 & 58.83 & 45.97 \\
\hline \multirow{5}{*}{ Southwest China } & Chongqing & 3281 & 120.10 & 91.96 & 71.94 \\
\hline & Sichuan & 3818 & 139.79 & 107.02 & 83.73 \\
\hline & Guizhou & 2521 & 92.29 & 70.68 & 55.22 \\
\hline & Yunnan & 2104 & 77.10 & 59.06 & 46.14 \\
\hline & Average & 3179 & 116.41 & 89.10 & 69.70 \\
\hline \multirow{4}{*}{ Loess plateau region of China } & Shanxi & 4073 & 149.09 & 114.22 & 89.28 \\
\hline & Shaanxi & 4185 & 153.15 & 117.45 & 91.80 \\
\hline & Gansu & 3522 & 128.89 & 98.77 & 77.18 \\
\hline & Average & 3940 & 144.27 & 110.56 & 86.44 \\
\hline \multirow{4}{*}{ Northwest arid region of China } & Inner Mongolia & 2821 & 103.24 & 79.08 & 61.82 \\
\hline & Ningxia & 3180 & 116.40 & 89.25 & 69.75 \\
\hline & Xinjiang & 5563 & 203.63 & 156.09 & 122.06 \\
\hline & Average & 4525 & 165.67 & 126.97 & 99.28 \\
\hline \multirow{3}{*}{ Tibetan plateau region of China } & Tibet & 6108 & 223.56 & 171.35 & 134.05 \\
\hline & Qinghai & 3818 & 139.79 & 107.02 & 83.73 \\
\hline & Average & 4445 & 162.68 & 124.67 & 97.43 \\
\hline
\end{tabular}

Unit: kg/ha.

3.3. Urea Application Rate for 100\% Middle-Late Straw Returning to the Field. Table 8 shows that according to the $\mathrm{C}$ : $\mathrm{N}$ adjustment targets of $35: 1,30: 1$, and $25: 1$ under the national actual average yield per unit area of middle-late rice, the urea application rate is about $97.5 \mathrm{~kg} / \mathrm{ha}, 127.5 \mathrm{~kg} / \mathrm{ha}$, and $172.5 \mathrm{~kg} / \mathrm{ha}$, respectively, for $100 \%$ middle-late rice straw returning to the field. From the results, the urea application rate at about $120-135 \mathrm{~kg} / \mathrm{ha}$ can generally meet the nitrogen demand for microbial decomposition of $100 \%$ middle-late rice straw returning to the field in China.

According to the $\mathrm{C}: \mathrm{N}$ adjustment targets of $35: 1,30: 1$, and 25:1 (Table 9), the urea application rate for $100 \%$ middle-late rice straw returning to the field is $95-180 \mathrm{~kg} / \mathrm{ha}$, $100-185 \mathrm{~kg} / \mathrm{ha}, 95-175 \mathrm{~kg} / \mathrm{ha}$, and $75-140 \mathrm{~kg} / \mathrm{ha}$, respectively, in four major middle-late rice production regions in China, including Middle-Lower Yangtze region, Northeast China, Southwest China, and South China.

3.4. Urea Application Rate for $100 \%$ Corn Straw Returning to the Field. The results in Table 10 show that according to the $\mathrm{C}: \mathrm{N}$ adjustment targets of $35: 1,30: 1$, and $25: 1$ under the national actual average yield per unit area of corn, the urea application rate is about $52.5 \mathrm{~kg} / \mathrm{ha}, 82.5 \mathrm{~kg} / \mathrm{ha}$, and 


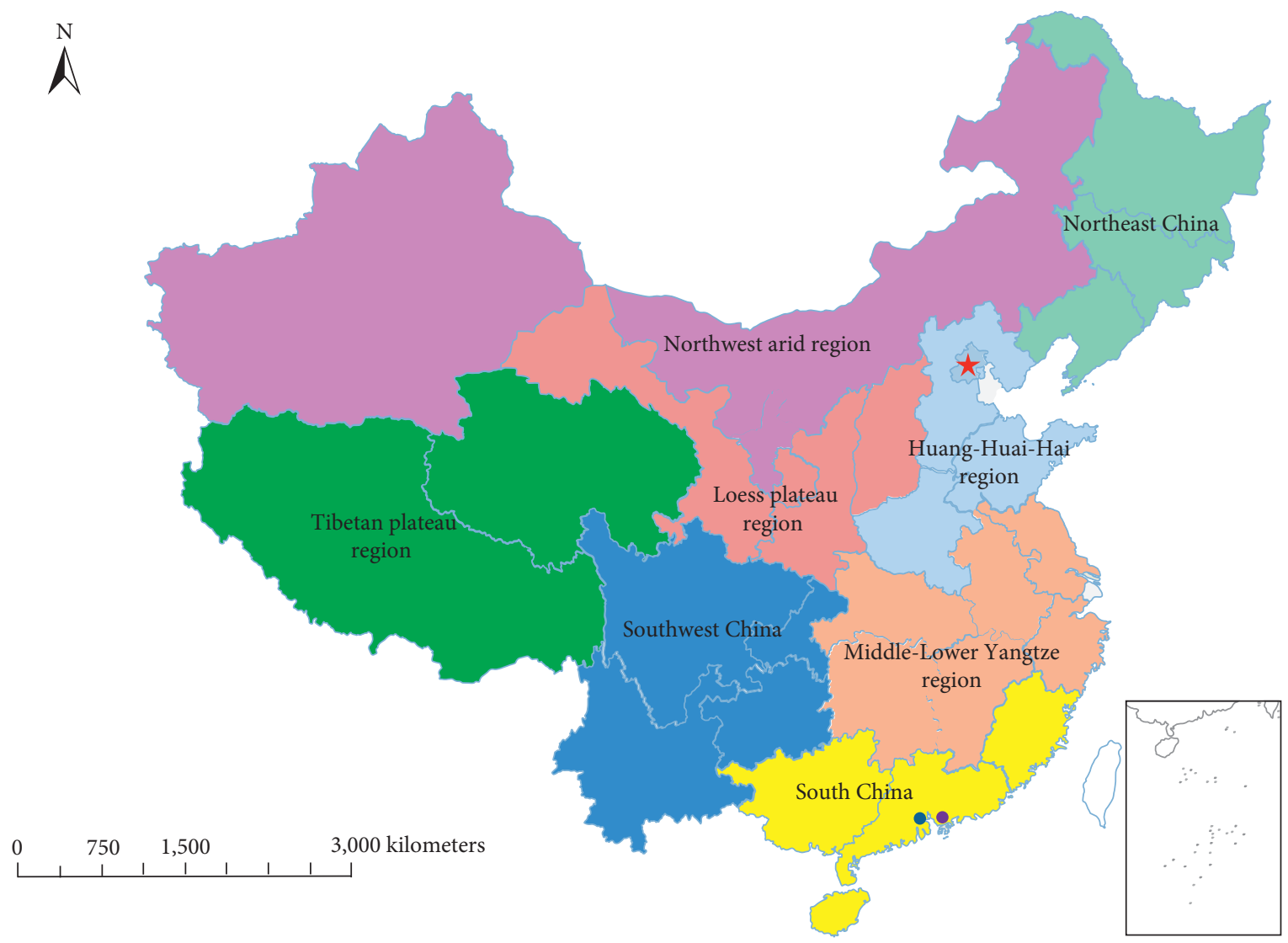

Figure 1: Major regions of China.

TABLE 6: Enquiry table for the urea application quantity of early rice straw returning to the field with different yields per unit area.

\begin{tabular}{lccc}
\hline & \multicolumn{3}{c}{ Urea dosages of different C: } \\
Yield per unit area of early rice & \multicolumn{3}{c}{ N adjustment targets } \\
& $25: 1$ & $30: 1$ & $35: 1$ \\
\hline 3750 & 62.40 & 45.75 & 33.90 \\
4125 & 68.70 & 50.40 & 37.35 \\
4500 & 74.85 & 55.05 & 40.80 \\
4875 & 81.15 & 59.55 & 44.10 \\
5250 & 87.45 & 64.20 & 47.55 \\
5625 & 93.60 & 68.70 & 51.00 \\
6000 & 97.35 & 71.55 & 52.95 \\
6375 & 106.05 & 77.85 & 57.75 \\
6750 & 112.35 & 82.50 & 61.20 \\
7125 & 118.65 & 87.00 & 64.50 \\
7500 & 124.80 & 91.65 & 67.95 \\
7875 & 131.10 & 96.30 & 71.40 \\
8250 & 137.25 & 100.80 & 74.70 \\
\hline
\end{tabular}

Unit: $\mathrm{kg} / \mathrm{ha}$.

$120 \mathrm{~kg} / \mathrm{ha}$, respectively, for $100 \%$ corn straw returning to the field. The urea application rate at about $75-90 \mathrm{~kg} / \mathrm{ha}$ can generally meet the nitrogen demand for microbial decomposition of $100 \%$ corn straw returning to the field in China.

In China, corn is widely planted, but more than $80 \%$ of the planting areas are mainly located in Northeast China, Huang-Huai-Hai region, Northwest arid region of China, and Southwest China. Table 11 shows that according to the $\mathrm{C}: \mathrm{N}$ adjustment targets of $35: 1,30: 1$, and $25: 1$, the urea application rate for returning $100 \%$ corn straw to the field is $60-135 \mathrm{~kg} / \mathrm{ha}, 50-115 \mathrm{~kg} / \mathrm{ha}, 60-135 \mathrm{~kg} / \mathrm{ha}$, and $45-105 \mathrm{~kg} /$ ha, respectively, in the abovementioned four regions.

\section{Discussion}

4.1. Application Rate of Nitrogen Fertilizers. The results indicate that adjustment targets of $\mathrm{C}: \mathrm{N}$ ratios are $35: 1,30: 1$, and $25: 1$; however, the suitable $\mathrm{C}: \mathrm{N}$ ratio adjustment target for $100 \%$ crop straw returning per unit area is $30: 1$. Based on the $\mathrm{C}: \mathrm{N}$ ratio of $30: 1$, the suitable rate of urea to apply for $100 \%$ wheat straw returning to the field is $150 \mathrm{~kg} / \mathrm{ha}$. For early rice, $75 \mathrm{~kg} / \mathrm{ha}$ of urea is required, while middle-late rice straw requires $120-135 \mathrm{~kg} /$ ha of urea. The urea application rate suitable for microbial decomposition for corn straw was $75-90 \mathrm{~kg} / \mathrm{ha}$. This indicates that, in returning $100 \%$ crop straw to the field, the rate of urea application to meet microbial decomposition varies from the type of crop straw and the season of planting (in the case of early and middle-late rice straw). Application of urea or other forms of $\mathrm{N}$ fertilizer is one of the effective ways of increasing crop productivity [31]. When large quantities of straws are returned to the soil, it promotes the crops' intake of $\mathrm{N}$ fertilizer [32]. Sustaining a reasonable quantity of $\mathrm{N}$ content in soils significantly improves crop productivity [9]. In addition, different methods of 
TABLE 7: Enquiry table for urea applied to early rice straw returning to the field in two major early rice areas and every provinces (cities, autonomous regions) in China.

\begin{tabular}{|c|c|c|c|c|c|}
\hline \multirow[t]{2}{*}{ Regions } & & \multirow[t]{2}{*}{$\begin{array}{l}\text { Average early rice yield per unit } \\
\text { from } 2015 \text { to } 2017\end{array}$} & \multicolumn{3}{|c|}{$\begin{array}{l}\text { Urea dosages of } \\
\text { different } \mathrm{C}: \mathrm{N} \\
\text { adjustment targets }\end{array}$} \\
\hline & & & $25: 1$ & $30: 1$ & $35: 1$ \\
\hline \multirow{6}{*}{ Early rice area in the Middle-Lower Yangtze Region of China } & Zhejiang & 6073 & 101.02 & 74.16 & 55.06 \\
\hline & Anhui & 5795 & 96.48 & 70.79 & 52.42 \\
\hline & Jiangxi & 5736 & 95.50 & 70.12 & 51.95 \\
\hline & Hubei & 5733 & 95.45 & 69.99 & 51.99 \\
\hline & Hunan & 5887 & 97.92 & 71.94 & 53.31 \\
\hline & Average & 5815 & 96.77 & 71.07 & 52.74 \\
\hline \multirow{6}{*}{ Early rice area in South China } & Fujian & 6069 & 100.95 & 74.21 & 54.98 \\
\hline & Guangdong & 5948 & 99.03 & 72.66 & 53.94 \\
\hline & Guangxi & 5918 & 98.43 & 72.36 & 53.64 \\
\hline & Hainan & 5612 & 93.43 & 68.51 & 50.90 \\
\hline & Yunnan & 5435 & 90.43 & 66.48 & 49.26 \\
\hline & Average & 5912 & 98.43 & 72.17 & 53.57 \\
\hline
\end{tabular}

Unit: $\mathrm{kg} / \mathrm{ha}$.

TABLE 8: Enquiry table for urea application quantity during middlelate rice straw returning to the field with different yields per unit area.

\begin{tabular}{lccc}
\hline & \multicolumn{3}{c}{$\begin{array}{c}\text { Urea dosages of } \\
\text { different C:N }\end{array}$} \\
Yield per unit area of middle-late rice & \multicolumn{3}{c}{ adjustment targets } \\
& $25: 1$ & $30: 1$ & $35: 1$ \\
\hline 4500 & 110.10 & 80.85 & 60.00 \\
4875 & 119.40 & 87.60 & 64.95 \\
5250 & 128.55 & 94.35 & 69.90 \\
5625 & 137.70 & 101.10 & 75.00 \\
6000 & 146.85 & 107.85 & 79.95 \\
6375 & 156.00 & 114.60 & 84.90 \\
6750 & 165.30 & 121.35 & 89.85 \\
7125 & 174.45 & 128.10 & 94.95 \\
7500 & 183.60 & 134.85 & 99.90 \\
7875 & 192.75 & 141.45 & 104.85 \\
8250 & 201.90 & 148.20 & 109.95 \\
8625 & 211.05 & 154.95 & 114.90 \\
9000 & 220.35 & 161.70 & 119.85 \\
9375 & 229.50 & 168.45 & 124.95 \\
9750 & 238.65 & 175.20 & 129.90 \\
\hline
\end{tabular}

Unit: $\mathrm{kg} / \mathrm{ha}$.

straw incorporation have been researched with the application of inorganic fertilizers. For instance, ammonium bicarbonate $\left(\mathrm{NH}_{4} \mathrm{HCO}_{3}\right)$ contains $17 \%$ of nitrogen, whereas diammonium phosphate $\left(\left(\mathrm{NH}_{4}\right)_{2} \mathrm{HPO}_{4}\right)$ contains $15-18 \%$ of nitrogen. The product specifications for diammonium phosphate fertilizers are $64 \%$ ( $18 \%$ of $\mathrm{N}+46 \%$ of $\mathrm{P} 2 \mathrm{O} 5), 62 \%$ $\left(17 \%\right.$ of $\mathrm{N}+45 \%$ of $\left.\mathrm{P}_{2} \mathrm{O}_{5}\right)$, and $57 \%\left(15 \%\right.$ of $\mathrm{N}+42 \%$ of $\left.\mathrm{P}_{2} \mathrm{O}_{5}\right)$. If ammonium bicarbonate or diammonium phosphate is used instead of urea, the application rate can be 2.5-3.0 times higher than that of urea under pure $\mathrm{N}$ content. In the past, $\mathrm{NH}_{4} \mathrm{HCO}_{3}$ was the leading $\mathrm{N}$ fertilizer that dominated the Chinese market, but from 1997 till date, urea has gradually replaced $\mathrm{NH}_{4} \mathrm{HCO}_{3}$ [33]. If nitrogen fertilizer or compound fertilizer is applied as the base fertilizer, the application rate of nitrogen fertilizer can be increased appropriately or highnitrogen compound fertilizer can be used instead of common compound fertilizer to complete the application of nitrogen fertilizer for straw returning to the field. Liao et al. [34] confirmed that when $\mathrm{N}$ fertilizer is added to the soil, the organic matter content of the soil increases. Nitrogen fertilizer is affected by organic matter and $\mathrm{pH}$ level of the soil. In addition, climatic conditions and soil characteristics might indirectly affect the nitrogen use efficiency at the regional levels [9]. The continuous application of nitrogen fertilization can have positive or negative effects on the soil depending on how it is applied. When $\mathrm{N}$ fertilizers are applied at the right time and rate, they enhance NUE in the soil and minimize environmental pollutions in the long term [35]. This can have a positive influence on the physical and chemical properties of the soil.

4.2. Nitrogen Application and Tillage. Returning straw to the field is categorized into direct and indirect straw returning methods. Direct returning of straw is normally associated with soil tillage [36]. The indirect method of straw returning is labour- and cost-intensive; hence, the direct application is mostly preferred [1]. Straw is returned to the field either by mulching, leaving tall straws on the field, and crushing mechanically with backward pressure return $[37,38]$. To meet global food security, there is the need to focus on returning straw to the field based on factors such as the right amount of $\mathrm{N}$ fertilizer, type of soil tillage, and the type of the cropping system [39].

The enquiry table for the rate of urea application for $100 \%$ straw returning to the field of the three major grain crops is mainly applicable to straw returning to the field by plough burying or rotary tillage incorporation. The technical key points of nitrogen fertilizer application for the two methods of straw returning to the field are to apply nitrogen fertilizer at the proper time and ensure the nitrogen fertilizer and the mechanically crushed straw mix thoroughly. When 
TABLE 9: Enquiry table for urea applied to middle-late rice straw returning to field in all regions of China and provinces (cities, autonomous regions).

\begin{tabular}{|c|c|c|c|c|c|}
\hline \multirow[t]{2}{*}{ Regions } & & \multirow{2}{*}{$\begin{array}{l}\text { Average middle-late rice yield per } \\
\text { unit from } 2015 \text { to } 2017\end{array}$} & \multicolumn{3}{|c|}{$\begin{array}{c}\text { Urea dosages of different } \mathrm{C} \text { : } \\
\mathrm{N} \text { adjustment targets }\end{array}$} \\
\hline & & & $25: 1$ & $30: 1$ & $35: 1$ \\
\hline \multirow{4}{*}{ Northeast China } & Liaoning & 8589 & 210.30 & 154.39 & 114.37 \\
\hline & Jilin & 8330 & 203.97 & 149.64 & 110.92 \\
\hline & Heilongjiang & 7062 & 172.88 & 126.85 & 94.01 \\
\hline & Average & 7444 & 182.20 & 133.72 & 99.20 \\
\hline \multirow{6}{*}{ Huang-Huai-Hai region of China } & Beijing & 6000 & 146.85 & 107.85 & 79.95 \\
\hline & Tianjin & 8019 & 196.35 & 144.04 & 106.87 \\
\hline & Hebei & 6614 & 161.83 & 118.78 & 88.04 \\
\hline & Shandong & 8257 & 202.07 & 148.33 & 110.04 \\
\hline & Henan & 8094 & 198.15 & 145.39 & 107.77 \\
\hline & Average & 7973 & 195.13 & 143.27 & 106.26 \\
\hline \multirow{8}{*}{ The Middle-Lower Yangtze region of China } & Shanghai & 8468 & 207.28 & 152.12 & 112.86 \\
\hline & Jiangsu & 8465 & 207.27 & 152.19 & 112.72 \\
\hline & Zhejiang & 7321 & 179.27 & 131.57 & 97.51 \\
\hline & Anhui & 6392 & 156.50 & 114.94 & 85.08 \\
\hline & Jiangxi & 6285 & 153.90 & 112.95 & 83.70 \\
\hline & Hubei & 8562 & 209.63 & 153.85 & 114.11 \\
\hline & Hunan & 6705 & 164.10 & 120.45 & 89.25 \\
\hline & Average & 7258 & 177.70 & 130.46 & 96.72 \\
\hline \multirow{5}{*}{ South China } & Fujian & 6200 & 151.77 & 111.39 & 82.57 \\
\hline & Guangdong & 5615 & 137.37 & 100.89 & 74.77 \\
\hline & Guangxi & 5584 & 136.75 & 100.27 & 74.45 \\
\hline & Hainan & 4589 & 112.33 & 82.48 & 61.19 \\
\hline & Average & 5671 & 138.77 & 101.87 & 75.61 \\
\hline \multirow{5}{*}{ Southwest China } & Chongqing & 7375 & 180.48 & 132.51 & 98.18 \\
\hline & Sichuan & 7829 & 191.68 & 140.68 & 104.24 \\
\hline & Guizhou & 6326 & 154.85 & 113.63 & 84.25 \\
\hline & Yunnan & 5957 & 145.85 & 106.99 & 79.38 \\
\hline & Average & 7086 & 173.40 & 127.31 & 94.43 \\
\hline \multirow{4}{*}{ Loess plateau region of China } & Shanxi & 6818 & 166.93 & 122.57 & 90.81 \\
\hline & Shaanxi & 7531 & 184.37 & 135.32 & 100.36 \\
\hline & Gansu & 6894 & 168.75 & 123.94 & 91.87 \\
\hline & Average & 7503 & 183.67 & 134.90 & 99.94 \\
\hline \multirow{4}{*}{ Northwest arid region of China } & Inner Mongolia & 6731 & 164.75 & 120.98 & 89.65 \\
\hline & Ningxia & 8356 & 204.47 & 150.17 & 111.31 \\
\hline & Xinjiang & 9079 & 222.25 & 163.12 & 120.95 \\
\hline & Average & 7903 & 193.45 & 142.01 & 105.27 \\
\hline \multirow{3}{*}{ Tibetan plateau region of China } & Tibet & 5556 & 136.05 & 99.86 & 74.03 \\
\hline & Qinghai & - & - & - & - \\
\hline & Average & 5556 & 136.05 & 99.86 & 74.03 \\
\hline
\end{tabular}

Unit: kg/ha.

straws are ploughed into the soil, it hastens decomposition and organic carbon accumulation [1].

When returning straw to the field through ploughing and incorporating it into the soil, it is preeminent to mechanically crush the straw once or twice and then the moldboard plough or the reversible plough, pulled by a highpowered tractor, rolls and buries the straw into the bottom of the tillage layer along with the nitrogen fertilizer to be applied. For straw returning to the field by rotary tillage incorporation, the nitrogen fertilizer can be mixed with the straw during secondary straw crushing or rotary tillage soil preparation.

For straw returning to the field by no-tillage mulching, the straw just covers the soil surface, and in the process of microbial decomposition of straw, it can absorb an amount of nitrogen from rainwater and the atmosphere. The microbial decomposition of surface straw is not in conflict with nitrogen absorption in the root zone of the crop. Therefore, for straw returning to the field by no-tillage mulching, the amount of urea or ammonium bicarbonate and diammonium phosphate corresponding to pure $\mathrm{N}$ content can be applied according to one-third to half of the amount in the enquiry table of urea application rate for $100 \%$ straw returning to the field. Wheat straw no-tillage mulching with corn direct seeding has become the most important method of straw returning to the field by no-tillage mulching in China, and the annual implementation area in China is up to more than $8 \times 10^{6}$ ha. At present, for wheat straw no-tillage 
TABLE 10: Enquiry table for urea application quantity of corn straw returning to the field with different yields per unit area.

\begin{tabular}{lccc}
\hline & \multicolumn{3}{c}{ Urea dosages of different C:N } \\
Yield per unit area of corn & $25: 1$ & $30: 1$ & $35: 1$ \\
\hline 3000 & 59.40 & 40.65 & 27.30 \\
3375 & 66.75 & 45.75 & 30.75 \\
3750 & 74.25 & 50.85 & 34.05 \\
4125 & 81.60 & 55.95 & 37.50 \\
4500 & 89.10 & 61.05 & 40.95 \\
4875 & 96.45 & 66.00 & 44.25 \\
5250 & 103.95 & 71.10 & 47.70 \\
5625 & 111.30 & 76.20 & 51.15 \\
6000 & 118.80 & 81.30 & 54.60 \\
6375 & 126.15 & 86.40 & 57.90 \\
6750 & 133.65 & 91.50 & 61.35 \\
7125 & 141.00 & 96.60 & 64.80 \\
7500 & 148.50 & 101.70 & 68.25 \\
7875 & 155.85 & 106.80 & 71.55 \\
8250 & 163.35 & 111.75 & 75.00 \\
8625 & 170.70 & 116.85 & 78.45 \\
9000 & 178.20 & 121.95 & 81.75 \\
\hline
\end{tabular}

Unit: kg/ha.

mulching with corn direct seeding (summer corn) in HuangHuai-Hai and other regions in general, phosphorus and potassium fertilizer are used as the base fertilizer. $40 \%$ of $\mathrm{N}$ fertilizer is applied as base fertilizer, and $60 \%$ is for topdressing. The corn seedling stage is the main decomposition stage of wheat straw. To avoid competition between microbial decomposition of wheat straw and the growth of corn seedlings for nitrogen fertilizer, the proportion of nitrogen fertilizer applied can be adjusted from 40:60 as the base fertilizer and topdressing to 40:40 (base fertilizer: topdressing). Applying urea as a single basal fertilizer is an effective approach to increasing yield and it saves time and energy [40]. When both straw and $\mathrm{N}$ fertilizer are applied, the process of ureolysis progresses at the presowing and filling stage which pertains to when basal and topdressing fertilizer application is done [41]. At present, the application rate of pure $\mathrm{N}$ for summer corn in regions such as HuangHuai-Hai region is $300-375 \mathrm{~kg} / \mathrm{ha}$, and there is no need to increase the application rate of nitrogen fertilizer for wheat straw returning to the field by mulching (with no-tillage corn direct seeding). The quantity of $\mathrm{N}$ fertilizer applied in combination with straws incorporated in the soil has a significant effect on crop yield. Similarly, the type of fertilizer and right application rate are vital towards crop yield [39]. Therefore, to guarantee sustainability, it is important to retain an adequate amount of fertilizer and ensure that the fertilizer distribution in soils is balanced [8].

4.3. Nitrogen Fertilizer Application in Regions of China. The results indicate the rate of urea application for returning $100 \%$ of straw to the field to meet microbial decomposition in regions and provinces in China. For wheat straw, $135-230 \mathrm{~kg} / \mathrm{ha}, \quad 110-190 \mathrm{~kg} / \mathrm{ha}, \quad 85-145 \mathrm{~kg} / \mathrm{ha}$, and $95-165 \mathrm{~kg} / \mathrm{ha}$ of urea can be applied in Huang-Huai-Hai,
Middle-Lower Yangtze, Loess plateau, and Northwest arid regions, respectively. Early rice straw required $52.5-98.5 \mathrm{~kg} /$ ha of urea in the Middle-Lower Yangtze region and South China, while middle-late rice straws requires $95-180 \mathrm{~kg} / \mathrm{ha}$, $100-185 \mathrm{~kg} / \mathrm{ha}, 95-175 \mathrm{~kg} / \mathrm{ha}$, and $75-140 \mathrm{~kg} / \mathrm{ha}$ in MiddleLower Yangtze region, Northeast China, Southwest China, and South China, respectively. Similarly, the rate of urea application for corn straw is $60-135 \mathrm{~kg} / \mathrm{ha}, 50-115 \mathrm{~kg} / \mathrm{ha}$, $60-135 \mathrm{~kg} / \mathrm{ha}$, and $45-105 \mathrm{~kg} / \mathrm{ha}$ in four major regions, namely, Northeast China, Huang-Huai-Hai, Northwest arid, and Southwest China, respectively. The findings confirm the need to apply an accurate amount of urea when returning $100 \%$ of a specific crop straw to the field to aid microbial decomposition. Hence, the application rate of urea is vital and depends on the geographical location, soil, and climatic conditions along with the type of crop straw applied. An important factor that affects the decomposition of straw is the $\mathrm{C}: \mathrm{N}$ ratio [42]. $0.8 \mathrm{~g}$ of nitrogen is required for every $100 \mathrm{~g}$ of straw decomposed by soil microorganisms, and a 25-30:1 C: $\mathrm{N}$ ratio is required for this decomposition [43]. For the areas where the nitrogen fertilizer is intensively overapplied, the nitrogen fertilizer application for $100 \%$ straw returning to the field can be carried out according to the $\mathrm{C}: \mathrm{N}$ adjustment target as $35: 1$. In fields where $\mathrm{N}, \mathrm{P}$, and $\mathrm{K}$ nutrients are not well balanced and nitrogen fertilizer is relatively deficient, the nitrogen fertilizer application for $100 \%$ straw returning to the field can be carried out according to the $\mathrm{C}: \mathrm{N}$ adjustment target as $25: 1$. According to Moreno-Cornejo et al. [44], a C:N ratio of $25: 1$ influences the decomposition of straw that helps to release nitrogen. In addition, Zou et al. [45] reiterated that, after straw was returned to the field, the right amount of nitrogen fertilizer with a $C: N$ ratio of $25: 1$ was added. The $C: N$ ratio of straw was high during the first stage of decomposition but as decomposition progresses, the $\mathrm{C}: \mathrm{N}$ ratio decreases gradually. In this regard, there is the need for an accurate application of nitrogen at the early stages of straw returning. When the correct quantity of nitrogen fertilizer is applied, the nitrogen content of the soil can increase and minimize the $\mathrm{C}: \mathrm{N}$ ratio of the soil. The quantity of nitrogen fertilizer can be reduced in areas where straw decomposition agent is applied, but the amount of nitrogen fertilizer should not be completely omitted because of the application of the straw decomposition agent. When straw is returned to the field in combination with $\mathrm{N}$ fertilizer, the use of straw decomposition agents increases microorganisms reaction in the soil [1]. The application of the right amount of $\mathrm{N}$ fertilizer together with straw returning is an effective strategy to enrich soils and promote agricultural productivity.

4.4. Crop Cultivation Characteristics and Straw Returning to the Field. The $\mathrm{C}: \mathrm{N}$ of crop straws such as that of cucurbits and vegetables, tuber crops, and sugar-yielding crops is closer to the $\mathrm{C}: \mathrm{N}$ suitable for microbial decomposition of straw, and the straw of these crops is suitable for returning directly to the field. Direct returning of straw to the field enhances the proper development of the soil structure, accelerates the organic matter content of the soil, and serves 
TABLE 11: Enquiry table for urea applied to corn straw returning to the field in all regions of China and provinces (cities, autonomous regions).

\begin{tabular}{|c|c|c|c|c|c|}
\hline \multirow[t]{2}{*}{ Regions } & & \multirow{2}{*}{$\begin{array}{l}\text { Average corn yield per unit } \\
\quad \text { from } 2015 \text { to } 2017\end{array}$} & \multicolumn{3}{|c|}{$\begin{array}{c}\text { Urea dosages of different } \mathrm{C}: \mathrm{N} \\
\text { adjustment targets }\end{array}$} \\
\hline & & & $25: 1$ & $30: 1$ & $35: 1$ \\
\hline \multirow{4}{*}{ Northeast China } & Liaoning & 6334 & 125.48 & 85.85 & 57.64 \\
\hline & Jilin & 7654 & 151.58 & 103.70 & 69.64 \\
\hline & Heilongjiang & 6128 & 121.36 & 83.01 & 55.74 \\
\hline & Average & 6657 & 131.79 & 90.26 & 60.57 \\
\hline \multirow{6}{*}{ Huang-Huai-Hai region of China } & Beijing & 6574 & 130.13 & 89.10 & 59.75 \\
\hline & Tianjin & 5433 & 107.61 & 73.69 & 49.38 \\
\hline & Hebei & 5470 & 108.35 & 74.18 & 49.75 \\
\hline & Shandong & 6523 & 129.11 & 88.47 & 59.23 \\
\hline & Henan & 5401 & 106.97 & 73.16 & 49.07 \\
\hline & Average & 5799 & 114.78 & 78.52 & 52.75 \\
\hline \multirow{8}{*}{ The Middle-Lower Yangtze region of China } & Shanghai & 6635 & 131.35 & 89.92 & 60.35 \\
\hline & Jiangsu & 5568 & 110.17 & 75.53 & 50.60 \\
\hline & Zhejiang & 4437 & 87.84 & 60.16 & 40.31 \\
\hline & Anhui & 5367 & 106.29 & 72.71 & 48.72 \\
\hline & Jiangxi & 4281 & 84.72 & 57.98 & 38.90 \\
\hline & Hubei & 4592 & 90.94 & 62.22 & 41.73 \\
\hline & Hunan & 5421 & 107.37 & 73.43 & 49.25 \\
\hline & Average & 5170 & 102.35 & 70.13 & 47.05 \\
\hline \multirow{5}{*}{ South China } & Fujian & 4201 & 83.12 & 56.86 & 38.26 \\
\hline & Guangdong & 4434 & 87.78 & 60.07 & 40.30 \\
\hline & Guangxi & 4558 & 90.26 & 61.77 & 41.38 \\
\hline & Hainan & - & - & - & - \\
\hline & Average & 4519 & 89.48 & 61.25 & 41.14 \\
\hline \multirow{5}{*}{ Southwest China } & Chongqing & 5577 & 110.49 & 75.56 & 50.67 \\
\hline & Sichuan & 5635 & 111.50 & 76.34 & 51.24 \\
\hline & Guizhou & 4346 & 86.02 & 58.95 & 39.55 \\
\hline & Yunnan & 5039 & 99.73 & 68.24 & 45.74 \\
\hline & Average & 5167 & 102.29 & 70.09 & 47.03 \\
\hline \multirow{4}{*}{ Loess plateau region of China } & Shanxi & 5349 & 105.93 & 72.42 & 48.68 \\
\hline & Shaanxi & 4689 & 92.88 & 63.57 & 42.68 \\
\hline & Gansu & 5610 & 111.00 & 76.05 & 51.00 \\
\hline & Average & 5215 & 103.25 & 70.73 & 47.35 \\
\hline \multirow{4}{*}{ Northwest arid region of China } & Inner Mongolia & 6667 & 131.99 & 90.39 & 60.66 \\
\hline & Ningxia & 7189 & 142.30 & 97.39 & 65.37 \\
\hline & Xinjiang & 7457 & 147.64 & 101.13 & 67.82 \\
\hline & Average & 6859 & 135.83 & 93.00 & 62.30 \\
\hline \multirow{3}{*}{ Tibetan plateau region of China } & Tibet & 4685 & 92.78 & 63.48 & 42.58 \\
\hline & Qinghai & 6677 & 132.20 & 90.52 & 60.65 \\
\hline & Average & 6324 & 125.14 & 85.76 & 57.42 \\
\hline
\end{tabular}

Unit: kg/ha.

as a good source of soil carbon, nitrogen, and energy as well as a good medium for soil microbial activities [46, 47]. There is a high infestation level in crops straw of potatoes, cucurbits, and vegetables planted in structures and the crops planted in open fields such as cabbage, vegetables, garlic, onions, pepper, ginger, and others. This may often cause severe continuous cropping barriers due to high plants and soilborne pests and disease infestation. Therefore, it is not recommended to return these straws directly to the field. These straws can be used for composting before returning them to the field, and burying straws in ditches is one way of getting straws decomposed. The ditch-buried straw method is the appropriate technique of returning straw to the field in the context of sustainable agricultural production [1]. Technologies such as biogas fermentation (digestate) can also be considered before returning to the field or can be used in making fodder and base material for mushroom cultivation.

\section{Conclusions}

This research formulated the nitrogen fertilizer application rate based on the $\mathrm{C}: \mathrm{N}$ in crop straw and the amount of $\mathrm{N}$ needed for microbial decomposition. Under the adjustable $\mathrm{C}: \mathrm{N}$ targets, the urea application rate for returning $100 \%$ of wheat straw, early rice straw, middle-late rice straw, and corn 
straw to the field to meet the nitrogen demand for microbial decomposition was $150 \mathrm{~kg} / \mathrm{ha}, 75 \mathrm{~kg} / \mathrm{ha}, 120-135 \mathrm{~kg} / \mathrm{ha}$, and 75-90 kg/ha, respectively. The application rate for ammonium bicarbonate or diammonium phosphate was adjusted to 2.5-3 times higher than that of urea application rate. The urea application rate for returning $100 \%$ of straw to the field in different regions and provinces in China for wheat straw was 135-230 kg/ha, 110-190 kg/ha, 85-145 kg/ha, and 95-165 kg/ ha in Huang-Huai-Hai region, Middle-Lower Yangtze region, Loess plateau region, and Northwest arid region, respectively. Early rice straw required $52.5-98.5 \mathrm{~kg} / \mathrm{ha}$ of urea in MiddleLower Yangtze region and South China. In Middle-Lower Yangtze, Northeast China, Southwest China, and South China regions, the urea application rate for middle-late rice straw was $95-180 \mathrm{~kg} / \mathrm{ha}, \quad 100-185 \mathrm{~kg} / \mathrm{ha}, \quad 95-175 \mathrm{~kg} / \mathrm{ha}$, and $75-140 \mathrm{~kg} / \mathrm{ha}$, respectively. The corn straw urea application rate in Northeast China, Huang-Huai-Hai, Northwest arid region, and Southwest China was $60-135 \mathrm{~kg} / \mathrm{ha}, 50-115 \mathrm{~kg} / \mathrm{ha}$, $60-135 \mathrm{~kg} / \mathrm{ha}$, and $45-105 \mathrm{~kg} / \mathrm{ha}$, respectively. The amount of $\mathrm{N}$ fertilizer should be adjusted based on the methods of straw returning to the field, nitrogen application level, and climatic conditions of the regions. This substantial $\mathrm{N}$ input for stimulating straw decomposition may favor $\mathrm{N}$ losses with nitrate leaching and nitrous oxides emissions and hold a potential for soil $\mathrm{N}$ eutrophication in the long term if the level is not carefully adjusted to the $\mathrm{N}$ requirement of the subsequent crops and changes in soil organic matter levels.

\section{Data Availability}

The data of average wheat, rice, and corn yield per unit area from 2015 to 2017 used to support the findings of this study are included within the supplementary information files.

\section{Conflicts of Interest}

The authors declare no conflicts of interest.

\section{Authors' Contributions}

Conceptualization, methodology, visualization, formal analysis, and writing of the original draft were conducted by Y. W. Validation, resources, and review and editing were performed by H. W. Validation and formal analysis were carried out by C. G. Review and Editing and provision of resources were conducted by P. A. S. Conceptualization, supervision, and funding acquisition were performed by Y. B.

\section{Acknowledgments}

This work was supported by the National Science Foundation of China (41771569).

\section{Supplementary Materials}

Appendix 1: average wheat yield per unit area from 2015 to 2017. Appendix 2: average early rice yield per unit area from 2015 to 2017. Appendix 3: average middle-late rice yield per unit area from 2015 to 2017. Appendix 4: average corn yield per unit area from 2015 to 2017. (Supplementary Materials)

\section{References}

[1] Z. Jin, T. Shah, L. Zhang, H. Liu, S. Peng, and L. Nie, "Effect of straw returning on soil organic carbon in rice-wheat rotation system: a review," Food and Energy Security, vol. 9, no. 2, 2020.

[2] D. N. Chavarria, C. Pérez-Brandan, D. L. Serri et al., "Response of soil microbial communities to agroecological versus conventional systems of extensive agriculture," Agriculture, Ecosystems \& Environment, vol. 264, pp. 1-8, 2018.

[3] J. Y. Wang, J. X. Jia, and Z. Q. Xiong, "Water regime-nitrogen fertilizer-straw incorporation interaction: field study on nitrous oxide emissions from a rice agroecosystem in Nanjing, China," Agriculture, Ecosystems \& Environment, vol. 141, no. 3-4, pp. 437-446, 2011.

[4] M.O.A. Ministry of Agriculture Information Office, The Comprehensive Utilization Rate of Straw Is More than 80\% MOA, Beijing, China, 2016, http://www.moa.gov.cn/xw/ zwdt/201605/t20160526_5151375.htm.

[5] H. Y. Wang, F. Wang, and R. H. Sun, "Policies and regulations of crop straw utilization of foreign countries and its experience and inspiration for China," Transactions of the Chinese Society of Agricultural Engineering, vol. 32, no. 16, pp. 216222, 2016.

[6] X. L. Yang, Y. L. Lu, and Y. A. Tong, "Effects of long-term N application and straw returning on $\mathrm{N}$ budget under wheatmaize rotation system," Journal of Plant Nutrition and Fertilizer, vol. 19, no. 1, pp. 65-73, 2013.

[7] Z. H. Wang, X. J. Li, and X. T. Ju, "Ammonia volatilization loss from surface-broadcast urea: comparison of vented-and closed-chamber methods and loss in winter wheat-summer maize rotation in North China Plain," Communications in Soil Science and Plant Analysis, vol. 35, no. 19-20, 2004.

[8] A. Belay, A. Claassens, and F. Wehner, "Effect of direct nitrogen and potassium and residual phosphorus fertilizers on soil chemical properties, microbial components and maize yield under long-term crop rotation," Biology and Fertility of Soils, vol. 35, no. 6, pp. 420-427, 2002.

[9] Z. Quan, S. Li, X. Zhang et al., "Fertilizer nitrogen use efficiency and fates in maize cropping systems across China: field $15 \mathrm{~N}$ tracer studies," Soil and Tillage Research, vol. 197, Article ID 104498, 2020.

[10] Z. L. Zhu, "On the methodology of recommendation for the application rate of chemical fertilizer nitrogen to crops," Journal of plant nutrition and fertilizer, vol. 12, no. 1, pp. 1-4, 2006.

[11] W. F. Zhang, L. Ma, and G. Q. Huang, “The development and contribution of nitrogenous fertilizer in China and challenges faced by the country," Scientia Agricultura Sinica, vol. 46, no. 15, pp. 3161-3171, 2013.

[12] J. H. Guo, X. J. Liu, Y. Zhang et al., "Significant acidification in major Chinese croplands," Science, vol. 327, no. 5968, pp. 1008-1010, 2010.

[13] Q. X. Fang, Q. Yu, and E. L. Wang, "Soil nitrate accumulation, leaching and crop nitrogen use as influenced by fertilization and irrigation in an intensive wheat-maize double cropping system in the North China Plain," Plant and Soil, vol. 284, pp. 335-350, 2016.

[14] M. M. Han, W. Q. Li, and J. Chen, "Effects of straw returning and nitrogen application rate on grain yield and nitrogen use efficiency of winter wheat," Shandong Agricultural Sciences, vol. 49, no. 9, pp. 95-100, 2017. 
[15] X. Q. Hou, P. N. Wu, and Y. L. Wang, "Effects of returning straw with nitrogen application on soil water and nutrient status and yield of maize," Chinese Journal of Applied Ecology, vol. 29, no. 6, pp. 1928-1934, 2018.

[16] T. Henriksen and T. Breland, "Nitrogen availability effects on carbon mineralization, fungal and bacterial growth, and enzyme activities during decomposition of wheat straw in soil," Soil Biology and Biochemistry, vol. 31, no. 8, pp. 1121-1134, 1999.

[17] C. P. McSwiney and G. P. Robertson, "Nonlinear response of $\mathrm{N} 2 \mathrm{O}$ flux to incremental fertilizer addition in a continuous maize (Zea mays L.) cropping system," Global Change Biology, vol. 11, no. 10, pp. 1712-1719, 2005.

[18] C. M. Gu, T. M. Huang, and X. F. Zheng, "Effect of nitrogen fertilizer application on yield and nutrition uptake of winter wheat planted in straw return field," Journal of Northwest Forestry University, vol. 41, no. 10, pp. 79-87, 2013.

[19] J. Wang, D.-J. Wang, and G. Zhang, "Effects of different $\mathrm{N}$-fertilizer rates with straw incorporation on rice yield and economic benefit of rice-wheat rotation system in Taihu Lake region," Chinese Journal of Eco-Agriculture, vol. 19, no. 2, pp. 265-270, 2011.

[20] J. P. Burzaco, I. A. Ciampitti, and T. J. Vyn, "Nitrapyrin impacts on maize yield and nitrogen use efficiency with spring-applied nitrogen: field studies vs. Meta-analysis comparison," Agronomy Journal, vol. 106, no. 2, pp. 753-760, 2014.

[21] J. Wang, D. Wang, G. Zhang, and C. Wang, "Effect of wheat straw application on ammonia volatilization from urea applied to a paddy field," Nutrient Cycling in Agroecosystems, vol. 94, no. 1, pp. 73-84, 2012.

[22] Y. Y. Bi, "Study on straw resources evaluation and utilization in China," PH. D dissertation, Chinese Academy of Agricultural Sciences, Beijing, China, 2010.

[23] MOA, The Ministry of Agriculture of the People's Republic of China. NY/T90-2014 Rural Household Biogas Fermentation Process regulations (Appendix D), MOA, Beijing, China, 2014.

[24] X. Zuo, "A research on the development and utilization of the agricultural residues as new sources energy in China," PH. D dissertation, Chinese Academy of Agricultural Sciences, Beijing, China, 2015.

[25] MOA. Ministry of Agriculture of the People's Republic of China, China Agriculture Statistical Report, China Agricultural Press, Beijing, China, 2015.

[26] MOA. Ministry of Agriculture of the People's Republic of China, China Agriculture Statistical Report, China Agricultural Press, Beijing, China, 2016.

[27] MARA. Ministry of Agriculture and Rural Affairs of the People's Republic of China, China Agriculture Statistical Report, China Agricultural Press, Beijing, China, 2017.

[28] X. J. Li, Solid Waste Treatment and Recycling, Science press, Beijing, China, 2011.

[29] United States Department of Agriculture, Natural Resources Conservation Service. Carbon to Nitrogen Ratios in Cropping Systems, USDA, Washington, DC, USA, 2011, http://usda. gov/sqi.2011.1.

[30] Department of Soil Hygiene, Institute of Health, and Chinese Academy of Medical Sciences, "Composting principle and its application in practice," Foreign medical references (The hygiene section), vol. 2, pp. 69-71, 1977.

[31] D. Tilman, C. Balzer, J. Hill, and B. L. Befort, "Global food demand and the sustainable intensification of agriculture," Proceedings of the National Academy of Sciences, vol. 108, no. 50, pp. 20260-20264, 2011.
[32] X. B. Wang and D. X. Cai, "Effect of corn stover incorporated in dry farm on soil fertility," Agricultural Sciences in China, vol. 33, pp. 54-61, 2000.

[33] W. F. Zhang, J. J. Yi, and F. S. Zhang, Research Report of China Fertilizer Development in 2016, China Agricultural University Press, Beijing, China, 2017.

[34] Y.-1. Liao, S.-x. Zheng, J. Nie, J. Xie, Y.-h. Lu, and X.-b. Qin, "Long-term effect of fertilizer and rice straw on mineral composition and potassium adsorption in a reddish paddy soil," Journal of Integrative Agriculture, vol. 12, no. 4, pp. 694-710, 2013.

[35] P. Omara, L. Aula, and W. R. Raun, "Nitrogen uptake efficiency and total soil nitrogen accumulation in long-term beef manure and inorganic fertilizer application," International Journal of Agronomy, vol. 2019, Article ID 9594369, 6 pages, 2019, https://doi.org/10.1155/2019/9594369.

[36] X. W. Cui, Y. Z. Zhang, and J. S. Wu, "Research progress on the effects of returning straw to fields on soil quality and crop growth," Chinese Journal of Soil Science, vol. 45, pp. 15271532, 2014.

[37] W. Y. Xie, G. S. Fan, and H. P. Zhou, "Effect of Straw incorporation on corn yield and water use efficiency in arid farming areas," Chinese Society for Agricultural Machinery, vol. 42, pp. 60-67, 2011.

[38] P. J. Thorburn, E. A. Meier, K. Collins, and F. A. Robertson, "Changes in soil carbon sequestration, fractionation and soil fertility in response to sugarcane residue retention are sitespecific," Soil and Tillage Research, vol. 120, pp. 99-111, 2012.

[39] X. Lu, "A meta-analysis of the effects of crop residue return on crop yields and water use efficiency," PLoS One, vol. 15, no. 4, Article ID e0231740, 2020.

[40] J. Geng, Y. Sun, M. Zhang et al., "Long-term effects of controlled release urea application on crop yields and soil fertility under rice-oilseed rape rotation system," Field Crops Research, vol. 184, pp. 65-73, 2015.

[41] H. Li, Y. Zhang, S. Yang et al., "Variations in soil bacterial taxonomic profiles and putative functions in response to straw incorporation combined with $\mathrm{N}$ fertilization during the maize growing season," Agriculture, Ecosystems \& Environment, vol. 283, Article ID 106578, 2019.

[42] I. Trinsoutrot, S. Recous, B. Bentz, M. Linères, D. Chèneby, and B. Nicolardot, "Biochemical quality of crop residues and carbon and nitrogen mineralization kinetics under nonlimiting nitrogen conditions," Soil Science Society of America Journal, vol. 64, no. 3, pp. 918-926, 2000.

[43] E. A. Kochsick and M. H. J. Knops, "Effects of nitrogen availability on the fate of litter-carbon and soil organic matter decomposition," British Journal of Environment and Climate Change, vol. 3, no. 24-43, 2013.

[44] J. Moreno-Cornejo, R. Zornoza, and A. Faz, "Carbon and nitrogen mineralization during decomposition of crop residues in a calcareous soil," Geoderma, vol. 230-231, pp. 58-63, 2014.

[45] H. Zou, X. Ye, J. Li et al., "Effects of straw return in deep soils with urea addition on the soil organic carbon fractions in a semi-arid temperate cornfield," PLoS One, vol. 11, no. 4, Article ID e0153214, 2016.

[46] P. Perucci, "Enzyme activity and microbial biomass in a field soil amended with municipal refuse," Biology and Fertility of Soils, vol. 14, no. 1, pp. 54-60, 1992.

[47] Y. Lou, M. Xu, W. Wang, X. Sun, and K. Zhao, "Return rate of straw residue affects soil organic $\mathrm{C}$ sequestration by chemical fertilization," Soil and Tillage Research, vol. 113, no. 1, pp. 70-73, 2011. 